\title{
BEBERAPA METODE STRESSING UNTUK MENGINDUKSI PERKEMBANGAN WHITE SPOT SYNDROME VIRUS(WSSV) PADA BENUR UDANG WINDU (Penaeus monodon)
}

\author{
Muliani, Bunga Rante Tampangallo, dan Koko Kurniawan \\ Balai Penelitian dan Pengembangan Budidaya Air Payau \\ Jl. Makmur Dg. Sitakka No. 129, Maros 90512, Sulawesi Selatan \\ E-mail: mulianim@yahoo.com
}

(Naskah diterima: 16 Februari 2012; Disetujui publikasi: 14 September 2012)

\begin{abstract}
ABSTRAK
Penelitian ini bertujuan untuk mengetahui beberapa model metode stressing yang dapat menginduksi perkembangan WSSV pada benur, sehingga dapat terdeteksi dengan PCR konvensional. Penelitian dilakukan di Laboratorium Basah Balai Penelitian dan Pengembangan Budidaya Air Payau (BPPBAP). Wadah yang digunakan adalah kontainer plastik bervolume $40 \mathrm{~L}$ diisi dengan air laut sebanyak $30 \mathrm{~L}$ dan dilengkapi dengan aerasi kecuali pada perlakuan oksigen. Setiap wadah ditebari benur (PL-12) sebanyak 500 ekor yang diambil dari panti perbenihan komersil di Kabupaten Barru yang sebelumnya telah diketahui negatif WSSV. Perlakuan yang dicobakan adalah: (A) stressing dengan suhu yaitu: $10^{\circ} \mathrm{C} \pm 2^{\circ} \mathrm{C}, 28^{\circ} \mathrm{C} \pm 2^{\circ} \mathrm{C}$, dan $40^{\circ} \mathrm{C} \pm 2^{\circ} \mathrm{C}$; (B) stressing dengan salinitas yaitu: $5 \mathrm{ppt}, 28 \mathrm{ppt}$, dan $51 \mathrm{ppt}$; (C) stressing dengan oksigen yaitu: $1 \mathrm{mg} / \mathrm{L}, 3 \mathrm{mg} / \mathrm{L}$, dan $5 \mathrm{mg} / \mathrm{L}$; (D) stressing dengan $\mathrm{pH}$ yaitu: $\mathrm{pH} 5, \mathrm{pH} 6$, dan $\mathrm{pH} 7$; dan (E) stressing dengan formalin yaitu: $100 \mathrm{mg} / \mathrm{L}, 200 \mathrm{mg} / \mathrm{L}$, dan $300 \mathrm{mg} / \mathrm{L}$. Sampling dilakukan 1 jam, 3 jam, dan 5 jam setelah perendaman untuk pengecekan WSSV dengan mengambil contoh benur sebanyak 50-100 ekor/wadah lalu dicek dengan PCR untuk WSSV-nya. Hasil penelitian menunjukkan bahwa stressing dengan oksigen ( $1 \mathrm{mg} / \mathrm{L}, 3$ $\mathrm{mg} / \mathrm{L}$, dan $5 \mathrm{mg} / \mathrm{L}$ ) memberikan hasil yang terbaik dalam memicu perkembangan WSSV pada benur, disusul dengan suhu (suhu $10^{\circ} \mathrm{C}$ dan $40^{\circ} \mathrm{C}$ ), $\mathrm{pH} 5$; kemudian penggunaan formalin, dan salinitas. Hasil PCR menunjukkan bahwa benur yang awalnya negatif menjadi positif dengan kategori ringan hingga berat. Semakin lama waktu perendaman maka semakin memicu perkembangan WSSV dalam badan benur.
\end{abstract}

KATA KUNCl: screening, stressing, induksi, udang windu, white spot syndrome virus, PCR

ABSTRACT: Some stressing method to develop WSSV induction on tiger shrimp (Penaeus monodon) larvae. By: Muliani, Bunga Rante Tampangallo, and Koko Kurniawan

The experiment aimed to know several of stressing methode to induce WSSV development on tiger shrimp post larvae that able to detected by PCR conventional methode. This experiment was conducted in wet laboratory of the Research Institute for Coastal Aquaculture (RICA), Maros. Plastic container vol $40 \mathrm{~L}$ was used for post larvae rearing, filled $30 \mathrm{~L}$ sea water and aerated except on oxygen treatment. Each container stocked with 500 pCs of negative WSSV tiger shrimp post larvae (PL-12) obtained from commercial hatchery in Barru. The treatment were (A) stressing temperature i.e; $10^{\circ} \mathrm{C} \pm 2^{\circ} \mathrm{C}, 28^{\circ} \mathrm{C} \pm 2^{\circ} \mathrm{C}$, and $40^{\circ} \mathrm{C} \pm 2^{\circ} \mathrm{C}$; (B) stressing with salinity i.e.; 5 ppt, $28 \mathrm{ppt}$, and $51 \mathrm{ppt}$; (C) stressing with oxygen i.e.; $1 \mathrm{mg} / \mathrm{L}, 3 \mathrm{mg} / \mathrm{L}$, and $5 \mathrm{mg} / \mathrm{L}$; 
(D) stressing with $\mathrm{pH}$ i.e. $\mathrm{pH} \mathrm{5,} \mathrm{pH} 6$, and $\mathrm{pH}$ 7; and (E) stressing with formaldehyd i.e.; $100 \mathrm{mg} / \mathrm{L}, 200 \mathrm{mg} / \mathrm{L}$, and $300 \mathrm{mg} / \mathrm{L}$. Sampling conducted 1 hour, 3 hours, 5 hours after bathing with 50-100 pieces of tiger shrimp post larvae/aquaria for WSSV detected. The effect of treatment on the development of WSSV on tiger shrimp post larvae, samples were detected by PCR conventional technique and data obtained analyzed descriptively. The result showed that stressing by oxygen $(1 \mathrm{mg} / \mathrm{L}, 3 \mathrm{mg} / \mathrm{L}$, and 5 $\mathrm{mg} / \mathrm{L}$ ) most effective impact to stimulated the development of WSSV in post larvae, followed by temperature, $\mathrm{pH}$, formaldehide, and salinity. PCR analysis showed that negative WSSV tiger shrimp post larvae initialy become medium WSSV positive until heavy WSSV positive after stressing. The longest of bathing would be resulted higher induction for development of WSSV in tiger shrimp post larvae.

KEYWORDS: screening, stressing, inducing, black tiger shrimp post larvae, White Spot Syndrome Virus, PCR

\section{PENDAHULUAN}

Penyakit WSSV atau dikenal dengan penyakit bintik putih merupakan jenis virus yang telah diidentifikasi menyerang baik induk udang windu (Muliani et al., 2005; Supriyadi et al., 2005), udang dewasa di tambak, maupun organisme liar seperti udang api-api, jembret, ikan liar, kepiting, dan beberapa jenis moluska yang hidup di tambak (Muliani et al., 2004), maupun plankton dan larva insekta (Corsin et al., 2005). Hal ini menunjukkan bahwa WSSV menyerang udang baik secara vertikal maupun horisontal (Muliani et al., 2004; SanchezMartinez et al., 2007).

Serangan WSSV pada budidaya udang windu sangat erat kaitannya dengan ada tidaknya infeksi WSSV pada benur atau tokolan udang yang digunakan. Kondisi ini sangat berhubungan dengan induk yang memproduksi benur tersebut. Karena induk yang terinfeksi WSSV akan diturunkan secara vertikal kepada larva/keturunannya. Menurut Peng et al. (2001), induk udang yang terinfeksi WSSV sebelum memijah, $75 \%$ nauplii yang dihasilkannya akan terinfeksi WSSV. Dengan demikian kualitas induk yang digunakan sangat mempengaruhi kualitas nauplii dan tentunya akan berlanjut ke post larva yang diproduksi, dan juga hasil pentokolan di tambak. Selanjutnya akan berdampak pada keberhasilan budidaya udang di tambak.

Program pemerintah tentang benur berlabel yang salah satu persyaratannya adalah bebas virus, termasuk WSSV harus segera diwujudkan untuk mencegah penyebaran infeksi virus di tambak melalui penularan dari benur. Untuk itu, screening benur sebelum ditebar di tambak merupakan kebutuhan utama guna memperkecil risiko kegagalan panen.
Teknik screening benur yang dilakukan selama ini belum berfungsi secara maksimal untuk menghasilkan benur yang benar-benar bebas WSSV. Oleh karena itu, teknik screening benur perlu dikembangkan sehingga benur yang ditebar di tambak benar-benar telah bebas dari WSSV.

Metode screening benur yang umum dilakukan adalah: (1) perendaman dalam formalin 150-200 mg/L yang dimaksudkan untuk mengetahui vitalitas benur dan (2) deteksi PCR untuk mengetahui ada tidaknya infeksi WSSV atau jenis virus lainnya. Persentase hasil deteksi WSSV antara yang positif dan negatif pada benur masih cukup rendah dibanding pada tokolan dan udang budidaya. Hal ini diduga bahwa tingkat infeksi serangan WSSV pada benur masih cukup rendah sehingga sulit untuk terdeteksi oleh metode yang digunakan.

Deteksi WSSV dengan PCR yang hasilnya menunjukkan negatif belum berarti bahwa benur tersebut betul-betul bebas WSSV, akan tetapi boleh jadi sudah ada WSSV tapi karena jumlah virionnya rendah sehingga tidak dapat terdeteksi oleh metode yang digunakan. Dalam proses analisis dengan PCR, ada beberapa hal yang dapat dilakukan untuk menstimulasi agar WSSV dapat terdeteksi, seperti menambah siklus PCR, menambah reagent PCR, atau bahkan mengklone sekuen DNA WSSV target dalam plasmid (Natividad et al., 2006). Di Thailand beberapa peneliti telah melakukan perbandingan beberapa metode untuk deteksi keberadaan WSSV pada benur udang (Sritunyalucksana et al., 2006), hal ini juga dimaksudkan agar hasil deteksi PCR benarbenar akurat sehingga WSSV dapat terdeteksi secara dini guna mencegah terjadinya peledakan penyakit di tambak pembesaran. Namun demikian konsekuensinya adalah 
penambahan biaya analisis. Oleh karena itu, diperlukan teknik untuk menginduksi perkembangan WSSV pada benur sebelum dideteksi dengan PCR sehingga prevalensi dan intensitasnya meningkat dan dapat terdeteksi secara dini, dengan demikian peledakan WSSV pada saat budidaya dapat dicegah. Induksi WSSV pada benur dapat dilakukan dengan metode stressing melalui kualitas air seperti penurunan dan peningkatan salinitas, oksigen, suhu, $\mathrm{pH}$, atau pemberian bahan kimia seperti formalin. Menurut Tendencia et al. (2010), bahwa salah satu faktor yang dapat memicu timbulnya penyakit WSSV karena adanya faktor stres pada udang. Selanjutnya dikatakan bahwa stressor untuk WSSV biasanya berhubungan dengan faktor fisika-kimiawi baik pada air maupun sedimen tambak dan hal tersebut dapat menstimulasi replikasi WSSV sehingga menyebabkan kematian pada udang.

Penelitian ini bertujuan untuk mengetahui beberapa jenis metode stressing yang dapat menginduksi perkembangan WSSV pada benur sehingga dapat dengan mudah terdeteksi dengan PCR.

\section{BAHAN DAN METODE}

Penelitian dilakukan di Laboratorium Basah Balai Penelitian dan Pengembangan Budidaya Air Payau (BPPBAP). Benur yang digunakan diambil dari panti perbenihan skala komersil yang ada di Kabupaten Barru dan Takalar, Sulawesi Selatan. Sebelum dilakukan stressing terlebih dahulu dilakukan pengambilan sampel untuk deteksi WSSV sebagai data awal. Benur untuk sampel awal dimasukkan ke dalam botol sampel yang telah berisi bahan pengawet berupa ethanol $70 \%$. Selanjutnya dibawa ke laboratorium Bioteknologi Balai Penelitian dan Pengembangan Budidaya Air Payau untuk deteksi WSSV dengan PCR. Sementara benur yang akan di-stressing dibawa ke Laboratorium Basah dengan kantong plastik dalam keadaan hidup. Selanjutnya, benur diaklimatisasi dalam bak fiber $500 \mathrm{~L}$ dengan diisi air laut salinitas 28 ppt selama 2-3 hari. Selanjutnya dilakukan stressing dengan metode: (A) penurunan dan peningkatan suhu; (B) penurunan dan peningkatan salinitas; (C) penurunan kadar oksigen; (D) penurunan kadar $\mathrm{pH}$; dan (E) penggunaan formalin. Setiap metode stressing diulang 3 kali. Wadah yang digunakan untuk uji stressing adalah kontainer plastik volume $50 \mathrm{~L}$ yang diisi air laut sebanyak $30 \mathrm{~L}$ dan dilengkapi dengan aerasi sebagai sumber oksigen kecuali pada perlakuan penurunan kadar oksigen. Setiap wadah diisi dengan air laut salinitas 28 ppt, kecuali pada perlakuan salinitas diisi air laut sesuai dengan tingkat salinitas yang diperlakukan.

Uji stressing dengan penurunan dan peningkatan suhu secara drastis diaplikasikan suhu $10^{\circ} \mathrm{C} \pm 2^{\circ} \mathrm{C}$, suhu ruang $\left(28^{\circ} \mathrm{C}\right)$, dan $40^{\circ} \mathrm{C} \pm 2^{\circ} \mathrm{C}$. Untuk mempertahankan suhu rendah sesuai dengan perlakuan, maka diberikan penambahan batu es yang dibuat dalam botol sehingga tidak mempengaruhi salinitas maupun volume air dalam wadah penelitian. Sementara untuk mempertahankan suhu tinggi sesuai perlakuan digunakan pemanas (heater).

Pada perlakuan stressing salinitas diaplikasikan salinitas 5 ppt, 28 ppt, dan 51 ppt. Penurunan dan peningkatan salinitas dilakukan dengan mengencerkan air laut salinitas 30 ppt hingga menjadi 5 dan 28 ppt, sedangkan untuk salinitas $51 \mathrm{ppt}$, dibuat dengan menambah garam dapur ke dalam air laut salinitas $30 \mathrm{ppt}$ hingga mencapai salinitas 51 ppt. Air laut bersalinitas 51 ppt kemudian disaring dan diendapkan sebelum dimasukkan ke dalam wadah penelitian.

Pada perlakuan stressing formalin, konsentrasi formalin yang digunakan adalah 100 $\mathrm{mg} / \mathrm{L}, 200 \mathrm{mg} / \mathrm{L}$, dan $300 \mathrm{mg} / \mathrm{L}$ dan untuk stressing dengan $\mathrm{pH}$ diberikan $\mathrm{pH}$ 5, 6, dan 7 . Pada stressing oksigen dicobakan kadar oksigen $1 \mathrm{mg} / \mathrm{L}, 3 \mathrm{mg} / \mathrm{L}$, dan $5 \mathrm{mg} / \mathrm{L}$. Untuk mendapatkan dan mempertahankan kadar oksigen yang dharapkan sesuai dengan perlakuan, maka ke dalam wadah penelitian dimasukkan ikan nila yang akan mengonsumsi oksigen dalam wadah penelitian.

Jumlah benur yang digunakan 500 ekor untuk setiap wadah. Untuk pengecekan WSSV contoh benur sebanyak 50-100 ekor/wadah diambil secara berkala yaitu: 1, 3, dan 5 jam tergantung kondisi benur. Jika benur sudah stres dan mengendap di dasar kontainer plastik, maka benur langsung dipanen semua. Sampel benur diawetkan dalam ethanol $70 \%$, kemudian selanjutnya dilakukan ekstraksi DNA menggunakan lisis buffer dan ekstraksi dTABCTAB agar diperoleh total DNA. Selanjutnya DNA WSSV diamplifikasi dengan teknik First dan Nested PCR menggunakan kit amplifikasi spesifik WSSV (IQ 2000TM WSSV Detection and Prevention System) (Anonymous, 2002), kemudian visualisasi DNA WSSV dilakukan dengan 
gel documentation dan sekaligus dilakukan pengambilan foto (Suwanto et al., 2000; Anonim, 2002; Sulandari \& Zei, 2003).

Untuk mengetahui suhu, salinitas, $\mathrm{pH}$, oksigen, dan konsentrasi formalin yang dapat memicu perkembangan WSSV, data dianalisis secara deskriptif. Data hasil PCR untuk deteksi WSSV yang diperoleh berupa data kualitatif (positif atau negatif WSSV).

\section{HASIL DAN BAHASAN}

Perbaikan teknik screening benur dirasa perlu untuk dilakukan demi mendapatkan benur yang lebih berkualitas. Penelitian yang mengarah ke hal tersebut telah dilakukan yaitu dengan melakukan stressing sebelum benur tersebut di-screening melalui teknik PCR. Screening dengan formalin dilakukan untuk mengetahui vitalitas benur, dan hal ini tidak diikuti oleh pemeriksaan WSSV dengan PCR. Uji stressing pada benur dengan tujuan untuk menginduksi perkembangan WSSV dilakukan terhadap benur yang dikoleksi dari panti perbenihan komersial yang ada di Kabupaten Barru, Sulawesi Selatan. Hasil deteksi dengan PCR menunjukkan bahwa sebelum dilakukan uji stressing, sampel benur terdeteksi negatif WSSV. Uji stressing dalam penelitian ini dibagi ke dalam 2 kelompok uji yaitu stressing fisik suhu, salinitas, dan oksigen, sedangkan stressing kimiawi terdiri atas $\mathrm{pH}$ dan formalin.

\section{Stressing Secara Fisika}

\section{Stressing dengan Peningkatan dan Penurunan Suhu Air}

Hasil uji stressing dengan penurunan dan peningkatan suhu disajikan pada Tabel 1. Pada tabel tersebut terlihat bahwa pada suhu $10^{\circ} \mathrm{C}$

Tabel 1. Hasil deteksi WSSV dengan teknik PCR pada benur udang windu sebelum dan sesudah stressing dengan suhu

Table 1. WSSV detection result using PCR technique on tiger shrimp post larvae before and after temperature stressing

\begin{tabular}{|c|c|c|c|}
\hline $\begin{array}{l}\text { Perlakuan } \\
\text { Treatments }\end{array}$ & $\begin{array}{l}\text { Wakt u sampling } \\
\text { Sampling period }\end{array}$ & $\begin{array}{l}\text { Hasil analisis PCR } \\
\text { PCR analysis results }\end{array}$ & $\begin{array}{l}\text { Tingkat infeksi } \\
\text { Infection level }\end{array}$ \\
\hline & $\begin{array}{l}\text { Sebelum uji stres } \\
\text { Before stress test }\end{array}$ & Negatif (Negative) & - \\
\hline \multirow{3}{*}{$\begin{array}{l}\mathrm{A} 1=\text { Suhu } 10^{\circ} \mathrm{C} \\
\mathrm{Al}=\text { Temperature } 10^{\circ} \mathrm{C}\end{array}$} & $\begin{array}{l}1 \text { jam perendaman } \\
1 \text { hour bathing }\end{array}$ & Positif (Positive) & Ringan (Light) \\
\hline & $\begin{array}{l}3 \text { jam perendaman } \\
3 \text { hours bathing }\end{array}$ & Positif (Positive) & Ringan (Light) \\
\hline & $\begin{array}{l}5 \text { jam perendaman } \\
5 \text { hours bathing }\end{array}$ & Positif (Positive) & Sedang (Medium) \\
\hline \multirow{3}{*}{$\begin{array}{l}\mathrm{A} 2=\text { Suhu } 28^{\circ} \mathrm{C} \\
\mathrm{A} 2=\text { Temperature } 28^{\circ} \mathrm{C}\end{array}$} & $\begin{array}{l}1 \text { jam perendaman } \\
1 \text { hour bathing }\end{array}$ & Positif (Positive) & Ringan (Light) \\
\hline & $\begin{array}{l}3 \text { jam perendaman } \\
3 \text { hours bathing }\end{array}$ & Positif (Positive) & Ringan (Light) \\
\hline & $\begin{array}{l}5 \text { jam perendaman } \\
5 \text { hours bathing }\end{array}$ & Positif (Positive) & Sedang (Medium) \\
\hline \multirow{3}{*}{$\begin{array}{l}\mathrm{A} 3=\text { Suhu } 40^{\circ} \mathrm{C} \\
A 3=\text { Temperature } 40^{\circ} \mathrm{C}\end{array}$} & $\begin{array}{l}1 \text { jam perendaman } \\
1 \text { hour bathing }\end{array}$ & Positif (Positive) & Ringan (Light) \\
\hline & $\begin{array}{l}3 \text { jam perendaman } \\
3 \text { hours bathing }\end{array}$ & Negatif (Negative) & - \\
\hline & $\begin{array}{l}5 \text { jam perendaman } \\
5 \text { hours bathing }\end{array}$ & Positif (Positive) & Ringan (Light) \\
\hline
\end{tabular}


dan $28^{\circ} \mathrm{C}$ pada perendaman 1,3 , dan 5 jam menunjukkan hasil yang positif WSSV, sedangkan pada uji stressing dengan perlakuan suhu $40^{\circ} \mathrm{C}$, pada perendaman 1 dan 5 jam positif WSSV dan pada perendaman 3 jam menunjukkan hasil yang negatif WSSV. Hal ini menunjukkan bahwa stressing dengan penurunan dan peningkatan suhu memberikan efek pada perkembangan WSSV pada benur meskipun belum memperlihatkan konsistensi pada semua waktu perendaman. Menurut Lu-Qing et al. (2007), bahwa suhu air merupakan faktor lingkungan yang berpengaruh pada metabolisme, konsumsi oksigen, pertumbuhan, dan sintasan udang yang dibudidayakan. Sedangkan menurut Murdjani et al. (2007), suhu air di tambak ideal untuk budidaya udang windu intensif adalah $26^{\circ} \mathrm{C}-29^{\circ} \mathrm{C}$.

Kasus kematian udang di tambak akibat serangan WSSV seringkali terkait dengan suhu air (Du et al., 2008). Pada saat fluktuasi suhu yang terlalu ekstrim antara siang hari dan malam hari, terutama pada subuh hari yang biasanya disebut sebagai musim "bediding", merupakan penyebab terjadi kasus kematian udang di tambak. Jika fluktuasi suhu sangat tajam maka akan membuat udang menjadi stres dan mudah terserang penyakit, terutama WSSV. Menurut Tendecia et al. (2010), fluktuasi suhu yang ekstrim dan suhu air yang rendah merupakan penyebab terjadi infeksi WSSV, hal ini disebabkan karena pada suhu rendah, WSSV akan menggandakan diri lebih cepat. Fluktuasi suhu pada tambak yang terserang WSSV lebih tinggi $\left(9,5^{\circ} \mathrm{C}\right)$ dibanding fluktuasi suhu $\left(4,75^{\circ} \mathrm{C}\right)$ pada tambak yang tidak terinfeksi WSSV. Selanjutnya dikatakan bahwa infeksi WSSV pada udang windu dapat ditekan pada suhu air yang tinggi, fluktuasi salinitas yang kecil, keberadaan bakteri vibrio yang koloninya kuning lebih tinggi daripada yang koloninya hijau. Hal senada disampaikan oleh You et al. (2010) bahwa suhu yang lebih tinggi $\left(31^{\circ} \mathrm{C} \pm 0,5^{\circ} \mathrm{C}\right)$ sangat nyata mengurangi kematian udang yang terinfeksi WSSV dibanding suhu rendah $\left(27^{\circ} \mathrm{C} \pm 0,5^{\circ} \mathrm{C}\right)$ dan hal ini menunjukkan bahwa suhu yang tinggi menghambat replikasi virus WSSV dan sekaligus meningkatkan respons imun udang. Sedangkan Vidal et al. (2001) melaporkan bahwa ditemukan kematian 100\% pada udang yang terserang WSSV yang dipindahkan dari $32^{\circ} \mathrm{C}$ ke $25,8^{\circ} \mathrm{C} \pm 0,7^{\circ} \mathrm{C}$. Hal ini berbeda apa yang dilaporkan oleh Du et al. (2008) bahwa tidak ditemukan kematian pada cryfish (Procambarus clarkii) yang dipelihara pada suhu $10^{\circ} \mathrm{C} \pm 1^{\circ} \mathrm{C}$ setelah diuji tantang dengan WSSV, akan tetapi ditemukan $100 \%$ kematian cryfish setelah ditransfer ke suhu $24^{\circ} \mathrm{C} \pm 1^{\circ} \mathrm{C}$. $\mathrm{Hal}$ ini terjadi karena adanya perbedaan peningkatan jumlah virion WSSV, pada suhu $10^{\circ} \mathrm{C} \pm 1^{\circ} \mathrm{C}$ meningkat dari $10^{6}$ menjadi $10^{8}$ copy/mg jaringan insang sedangkan pada suhu $24^{\circ} \mathrm{C} \pm 1^{\circ} \mathrm{C}$ meningkat dari $10^{6}$ menjadi $10^{10} \mathrm{copy} / \mathrm{mg}$ jaringan insang.

\section{Stressing dengan Peningkatan dan Penurunan Salinitas}

Hasil uji stressing dengan salinitas disajikan pada Tabel 2. Pada tabel tersebut terlihat bahwa hasil deteksi PCR terhadap benur yang di-stressing dengan salinitas menunjukkan hasil yang negatif WSSV pada semua tingkat salinitas dan waktu perendaman. Hal ini menunjukkan bahwa stressing dengan salinitas pada penelitian ini tidak mampu memicu perkembangan WSSV pada benur. Kondisi benur pada stressing dengan salinitas memang berbeda dengan benur yang di-stressing dengan oksigen, $\mathrm{pH}$, suhu, dan formalin. Selama perendaman tidak ditemukan benur yang mengendap di dasar akuarium seperti hal pada perlakuan lainnya. Hal ini diduga karena udang windu memiliki kemampuan adaptasi terhadap perubahan salinitas yang cukup tinggi.

Jika dikaitkan dengan kondisi di lapangan (tambak) merebaknya penyakit bintik putih yang disebabkan oleh WSSV pada musim penghujan diduga bukan akibat penurunan salinitas oleh air hujan, melainkan karena goncangan suhu dan oksigen. Hal ini sejalan dengan yang disampaikan oleh Tendencia et al. (2010) bahwa fluktuasi salinitas yang terjadi di tambak bukanlah merupakan penyebab utama terjadinya serangan WSSV pada budidaya udang.

\section{Stressing dengan Penurunan Kadar Oksigen}

Hasil uji stressing dengan penurunan kadar oksigen disajikan pada Tabel 3. Pada tabel tersebut terlihat bahwa konsentrasi $1 \mathrm{mg} / \mathrm{L}, 3 \mathrm{mg} / \mathrm{L}$, dan $5 \mathrm{mg} / \mathrm{L}$ menunjukkan hasil yang positif WSSV pada semua waktu perendaman. Infeksi WSSV pada benur udang windu yang distreskan dengan kadar oksigen terutama $1 \mathrm{mg} / \mathrm{L}$ dan $3 \mathrm{mg} / \mathrm{L}$ tergolong pada tingkat serangan sedang hingga berat. Sedangkan pada konsentrasi $5 \mathrm{mg} / \mathrm{L}$ tingkat infeksi WSSV tergolong ringan (Tabel 3). Hal 
Tabel 2. Hasil deteksi WSSV dengan teknik PCR pada benur udang windu sebelum dan sesudah stressing dengan salinitas

Table 2. WSSV detection result using PCR technique on tiger shrimp post larvae before and after salinity stressing

\begin{tabular}{|c|c|c|c|}
\hline $\begin{array}{l}\text { Perlakuan } \\
\text { Treatments }\end{array}$ & $\begin{array}{l}\text { Wakt u sampling } \\
\text { Sampling period }\end{array}$ & $\begin{array}{l}\text { Hasil analisis PCR } \\
\text { PCR analysis results }\end{array}$ & $\begin{array}{l}\text { Tingkat infeksi } \\
\text { Infection level }\end{array}$ \\
\hline & $\begin{array}{l}\text { Sebelum uji stres } \\
\text { Before stress test }\end{array}$ & Negatif (Negative) & - \\
\hline \multirow{3}{*}{$\begin{array}{l}\mathrm{B} 1=\text { Salinitas } 5 \mathrm{ppt} \\
\mathrm{B} 1=\text { Salinity } 5 \mathrm{ppt}\end{array}$} & $\begin{array}{l}1 \text { jam perendaman } \\
1 \text { hour bathing }\end{array}$ & Negatif (Negative) & - \\
\hline & $\begin{array}{l}3 \text { jam perendaman } \\
3 \text { hours bathing }\end{array}$ & Negatif (Negative) & - \\
\hline & $\begin{array}{l}5 \text { jam perendaman } \\
5 \text { hours bathing }\end{array}$ & Negatif (Negative) & - \\
\hline \multirow{3}{*}{$\begin{array}{l}\mathrm{B} 2=\text { Salinitas } 28 \mathrm{ppt} \\
\mathrm{B} 2=\text { Salinity } 28 p p t\end{array}$} & $\begin{array}{l}1 \text { jam perendaman } \\
1 \text { hour bathing }\end{array}$ & Negatif (Negative) & - \\
\hline & $\begin{array}{l}3 \text { jam perendaman } \\
3 \text { hours bathing }\end{array}$ & Negatif (Negative) & - \\
\hline & $\begin{array}{l}5 \text { jam pe rendaman } \\
5 \text { hours bathing }\end{array}$ & Negatif (Negative) & - \\
\hline \multirow{3}{*}{$\begin{array}{l}\mathrm{B} 3=\text { Salinitas } 51 \mathrm{ppt} \\
\mathrm{B} 3=\text { Salinity } 51 \mathrm{ppt}\end{array}$} & $\begin{array}{l}1 \text { jam perendaman } \\
1 \text { hour bathing }\end{array}$ & Negatif (Negative) & - \\
\hline & $\begin{array}{l}3 \text { jam perendaman } \\
3 \text { hours bathing }\end{array}$ & Negatif (Negative) & - \\
\hline & $\begin{array}{l}5 \text { jam perendaman } \\
5 \text { hours bathing }\end{array}$ & Negatif (Negative) & - \\
\hline
\end{tabular}

ini menunjukkan bahwa kadar oksigen yang rendah membuat benur jadi stres yang akhirnya memicu perkembangan WSSV dalam badan benur. Hal seperti inilah yang sering terjadi di tambak, di mana fluktuasi oksigen yang terjadi dapat membuat udang menjadi stres dan lebih mudah terserang penyakit utamanya WSSV. Menurut Ivan (2005), oksigen terlarut di tambak budidaya udang sebaiknya lebih dari 3,5 mg/L. Timbulnya stres pada benur pada perlakuan dengan konsentrasi oksigen $5 \mathrm{mg} / \mathrm{L}$ sehingga terdeteksi positif WSSV meskipun masih pada taraf yang ringan diduga karena penurunan yang oksigen yang secara mendadak dari konsentrasi 6,5-7 mg/L di penampungan. Cordova-Murueta (2004) dan de la-Vega et al. (2007) melaporkan bahwa penyebab stres pada udang yang akan berakibat kepada timbulnya penyakit adalah kondisi lingkungan yang menurun dan penanganan yang buruk.

\section{Stressing Secara Kimiawi}

\section{Stressing dengan Penurunan $\mathrm{pH}$}

Hasil uji stressing benur udang windu dengan $\mathrm{pH}$ disajikan pada Tabel 4. Pada tabel tersebut terlihat bahwa hasil deteksi PCR terhadap benur yang di-stressing dengan $\mathrm{pH}$ 5 dan $\mathrm{pH} 6$ dengan waktu perendaman 1, 3, dan 5 jam menunjukkan hasil yang positif WSSV, sedangkan pada $\mathrm{pH} 7$ hanya pada perendaman 3 dan 5 jam yang menunjukkan hasil yang positif WSSV, sementara pada perendaman 1 jam hasilnya negatif WSSV. Meskipun hasil analisis PCR menunjukkan hasil yang positif WSSV, namun infeksi serangan WSSV pada benur masih tergolong ringan. Hal ini disebabkan kadar $\mathrm{pH}$ yang digunakan masih tinggi, bahkan $\mathrm{pH} 7$ masih merupakan $\mathrm{pH}$ normal bagi pertumbuhan udang. Oleh karena itu, untuk lebih memperjelas efek $\mathrm{pH}$ terhadap 
Tabel 3. Hasil deteksi WSSV dengan teknik PCR pada benur udang windu sebelum dan sesudah stressing dengan oksigen

Table 3. WSSV detection result using PCR technique on tiger shrimp post larvae before and after oxygen stressing

\begin{tabular}{|c|c|c|c|}
\hline $\begin{array}{l}\text { Perlakuan } \\
\text { Treatments }\end{array}$ & $\begin{array}{l}\text { Wakt u sampling } \\
\text { Sampling period }\end{array}$ & $\begin{array}{l}\text { Hasil analisis PCR } \\
\text { PCR analysis results }\end{array}$ & $\begin{array}{l}\text { Tingkat infeksi } \\
\text { Infection level }\end{array}$ \\
\hline & $\begin{array}{l}\text { Sebelum uji stres } \\
\text { Before stress test }\end{array}$ & Negatif (Negative) & - \\
\hline \multirow{3}{*}{$\begin{array}{l}\mathrm{D} 1=\text { Oksigen } 1 \mathrm{mg} / \mathrm{L} \\
\mathrm{D} 1=\text { Oxygen } 1 \mathrm{mg} / \mathrm{L}\end{array}$} & $\begin{array}{l}1 \text { jam perendaman } \\
1 \text { hour bathing }\end{array}$ & Positif (Positive) & Sedang (Medium) \\
\hline & $\begin{array}{l}3 \text { jam perendaman } \\
3 \text { hours bathing }\end{array}$ & Positif (Positive) & Berat (Severe) \\
\hline & $\begin{array}{l}5 \text { jam perendaman } \\
5 \text { hours bathing }\end{array}$ & Positif (Positive) & Berat (Severe) \\
\hline \multirow{3}{*}{$\begin{array}{l}\mathrm{D} 2=\text { Oksigen } 3 \mathrm{mg} / \mathrm{L} \\
\mathrm{D} 2=\text { Oxygen } 3 \mathrm{mg} / \mathrm{L}\end{array}$} & $\begin{array}{l}1 \text { jam perendaman } \\
1 \text { hour bathing }\end{array}$ & Positif (Positive) & Sedang (Medium) \\
\hline & $\begin{array}{l}3 \text { jam perendaman } \\
3 \text { hours bathing }\end{array}$ & Positif (Positive) & Berat (Severe) \\
\hline & $\begin{array}{l}5 \text { jam perendaman } \\
5 \text { hours bathing }\end{array}$ & Positif (Positive) & Berat (Severe) \\
\hline \multirow{3}{*}{$\begin{array}{l}\mathrm{D} 3=\text { Oksigen } 5 \mathrm{mg} / \mathrm{L} \\
\mathrm{D} 3=\text { Oxygen } 5 \mathrm{mg} / \mathrm{L}\end{array}$} & $\begin{array}{l}1 \text { jam perendaman } \\
1 \text { hour bathing }\end{array}$ & Positif (Positive) & Ringan (Light) \\
\hline & $\begin{array}{l}3 \text { jam perendaman } \\
3 \text { hours bathing }\end{array}$ & Positif (Positive) & Ringan (Light) \\
\hline & $\begin{array}{l}5 \text { jam pe rendaman } \\
5 \text { hours bathing }\end{array}$ & Positif (Positive) & Ringan (Light) \\
\hline
\end{tabular}

perkembangan WSSV pada benur diharapkan penelitian selanjutnya menggunakan kadar $\mathrm{pH}$ yang lebih rendah atau tinggi. Walaupun demikian dari hasil analisis PCR pada Tabel 4 tersebut terdapat indikasi bahwa semakin rendah $\mathrm{pH}$ dan semakin lama waktu perendaman maka benur semakin stres sehingga WSSV semakin berkembang dalam badan benur. Menurut Tendecia et al. (2010), bahwa fluktuasi temperatur dan $\mathrm{pH}$ merupakan faktor yang sangat penting terhadap serangan WSSV. $\mathrm{Hal}$ ini sejalan dengan yang dilaporkan oleh Lemonniera et al. (2004) bahwa pada pH air yang rendah $(5,9)$ menyebabkan pertumbuhan udang windu menurun akibat stres. Selanjutnya dikatakan bahwa penurunan $\mathrm{pH}$ air dari 7,0 menjadi 6,5 menyebabkan tekanan osmotik udang menurun secara nyata. Tentunya ini akan berakibat pada penurunan vitalitas udang sehingga udang akan lebih stres dan terserang penyakit (WSSV). Hal yang berbeda dilaporkan oleh Corsin et al. (2001) bahwa penyakit white spot biasanya timbul di saat $\mathrm{pH}$ air tinggi.

\section{Stressing dengan Konsentrasi Formalin yang Berbeda}

Hasil uji stressing dengan formalin disajikan pada Tabel 5. Pada tabel tersebut terlihat bahwa formalin dengan konsentrasi $100 \mathrm{mg} / \mathrm{L}, 200 \mathrm{mg} / \mathrm{L}$, dan $300 \mathrm{mg} / \mathrm{L}$ dapat menjadi stressor bagi perkembangan WSSV pada benur. Hal ini dapat dilihat pada hasil analisis PCR terhadap semua benur yang telah distreskan dengan formalin dengan waktu perendaman 1, 3, dan 5 jam, semua positif WSSV dengan infeksi ringan sampai sedang. Hal ini sejalan yang dilporkan oleh Muliani et al. (2011), bahwa penggunaan formalin sebagai bahan stressor dapat menginduksi 
Tabel 4. Hasil deteksi WSSV dengan teknik PCR pada benur udang windu sebelum dan sesudah stressing dengan $\mathrm{pH}$

Table 4. WSSV detection result using PCR technique on tiger shrimp post larvae before and after $\mathrm{pH}$ stressing

\begin{tabular}{|c|c|c|c|}
\hline $\begin{array}{l}\text { Perlakuan } \\
\text { Treatments }\end{array}$ & $\begin{array}{l}\text { Wakt u sampling } \\
\text { Sampling period }\end{array}$ & $\begin{array}{l}\text { Hasil analisis PCR } \\
\text { PCR analysis results }\end{array}$ & $\begin{array}{l}\text { Tingkat infeksi } \\
\text { Infection level }\end{array}$ \\
\hline & $\begin{array}{l}\text { Sebelum uji stres } \\
\text { Before stress test }\end{array}$ & Negatif (Negative) & - \\
\hline \multirow{3}{*}{$\mathrm{Cl}=\mathrm{pH} 5$} & $\begin{array}{l}1 \text { jam perendaman } \\
1 \text { hour bathing }\end{array}$ & Positif (Positive) & Ringan (Light) \\
\hline & $\begin{array}{l}3 \text { jam perendaman } \\
3 \text { hours bathing }\end{array}$ & Positif (Positive) & Ringan (Light) \\
\hline & $\begin{array}{l}5 \text { jam perendaman } \\
5 \text { hours bathing }\end{array}$ & Positif (Positive) & Ringan (Light) \\
\hline \multirow{3}{*}{$\mathrm{C} 2=\mathrm{pH} 6$} & $\begin{array}{l}1 \text { jam perendaman } \\
1 \text { hour bathing }\end{array}$ & Positif (Positive) & Ringan (Light) \\
\hline & $\begin{array}{l}3 \text { jam perendaman } \\
3 \text { hours bathing }\end{array}$ & Positif (Positive) & Ringan (Light) \\
\hline & $\begin{array}{l}5 \text { jam perendaman } \\
5 \text { hours bathing }\end{array}$ & Positif (Positive) & Ringan (Light) \\
\hline \multirow{3}{*}{$\mathrm{C} 3=\mathrm{pH} 7$} & $\begin{array}{l}1 \text { jam perendaman } \\
1 \text { hour bathing }\end{array}$ & Negatif (Negative) & - \\
\hline & $\begin{array}{l}3 \text { jam perendaman } \\
3 \text { hours bathing }\end{array}$ & Positif (Positive) & Ringan (Light) \\
\hline & $\begin{array}{l}5 \text { jam perendaman } \\
5 \text { hours bathing }\end{array}$ & Positif (Positive) & Ringan (Light) \\
\hline
\end{tabular}

perkembangan WSSV pada benur. Hasil penelitian Arimoto (1996) dalam Balasubramanian et al. (2006) yang mengatakan bahwa formalin tidak dapat me-non-aktifkan replikasi dari WSSV. Penggunaan formalin untuk screening benur sebelum ditebar di tambak seperti selama ini dilakukan di panti berbenihan sebetulnya sudah tepat, namun masih perlu dilanjutkan dengan deteksi PCR terhadap benur yang telah di-screening dengan formalin. Hal ini untuk memastikan apakah benur tersebut benar-benar tidak terinfeksi WSSV.

Dari semua metode stressing yang dicobakan, penurunan kadar oksigen merupakan metode stressing yang paling baik dalam menginduksi perkembangan WSSV pada benur. Berdasarkan hasil deteksi PCR terhadap benur yang telah distreskan, tingkat infeksi WSSV pada setiap metode berbeda satu sama lain (Gambar 1). Pada gambar tersebut terlihat bahwa hasil deteksi PCR terhadap benur yang telah di-stressing dengan oksigen (line 1-4), menunjukkan tingkat infeksi sedang sampai berat, stressing dengan salinitas (line 5-6), menunjukkan tidak ada infeksi WSSV, stressing dengan $\mathrm{pH}$ (line 8-9), yaitu infeksi ringan dan tidak ada infeksi pada $\mathrm{pH}$ dengan waktu perendaman 1 jam, stressing dengan formalin (line 10-11) menunjukkan infeksi WSSV pada tingkat sedang yaitu pada perendaman formalin $100 \mathrm{mg} / \mathrm{L}$ dan $200 \mathrm{mg} / \mathrm{L}$ pada perendaman 3 jam, dan stressing dengan suhu (line 12-14) menunjukkan tingkat infeksi sedang. Hasil PCR benur sebelum di-stressing terdapat pada line 7 menunjukkan negatif WSSV.

Tingkat infeksi WSSV pada benur yang distressing dengan penurunan kadar oksigen tergolong infeksi ringan pada konsentrasi $5 \mathrm{mg} / \mathrm{L}$, infeksi sedang hingga berat pada konsentrasi $3 \mathrm{mg} / \mathrm{L}$ dan $1 \mathrm{mg} / \mathrm{L}$. Metode stress- 
Tabel 5. Hasil deteksi WSSV dengan teknik PCR pada benur udang windu sebelum dan sesudah stressing dengan formalin

Table 5. WSSV detection result using PCR technique on tiger shrimp post larvae before and after formaldehide stressing

\begin{tabular}{|c|c|c|c|}
\hline $\begin{array}{l}\text { Perlakuan } \\
\text { Treatments }\end{array}$ & $\begin{array}{l}\text { Wakt u sampling } \\
\text { Sampling period }\end{array}$ & $\begin{array}{l}\text { Hasil analisis PCR } \\
\text { PCR analysis results }\end{array}$ & $\begin{array}{l}\text { Tingkat infeksi } \\
\text { Infection level }\end{array}$ \\
\hline & $\begin{array}{l}\text { Sebelum uji stres } \\
\text { Before stress test }\end{array}$ & Negatif (Negative) & - \\
\hline \multirow{3}{*}{$\begin{array}{l}\mathrm{E} 1=\text { Formalin } 100 \mathrm{mg} / \mathrm{L} \\
\mathrm{El}=\text { Formaldehyd } 100 \\
\mathrm{mg} / \mathrm{L}\end{array}$} & $\begin{array}{l}1 \text { jam perendaman } \\
1 \text { hour bathing }\end{array}$ & Positif (Positive) & Ringan (Light) \\
\hline & $\begin{array}{l}3 \text { jam perendaman } \\
3 \text { hours bathing }\end{array}$ & Positif (Positive) & Sedang (Medium) \\
\hline & $\begin{array}{l}5 \text { jam perendaman } \\
5 \text { hours bathing }\end{array}$ & Positif (Positive) & Ringan (Light) \\
\hline \multirow{3}{*}{$\begin{array}{l}\mathrm{E} 2=\text { Formalin } 200 \mathrm{mg} / \mathrm{L} \\
\mathrm{E} 2=\text { Formaldehyd } 200 \\
\mathrm{mg} / \mathrm{L}\end{array}$} & $\begin{array}{l}1 \text { jam perendaman } \\
1 \text { hour bathing }\end{array}$ & Positif (Positive) & Ringan (Light) \\
\hline & $\begin{array}{l}3 \text { jam perendaman } \\
3 \text { hours bathing }\end{array}$ & Positif (Positive) & Sedang (Medium) \\
\hline & $\begin{array}{l}5 \text { jam perendaman } \\
5 \text { hours bathing }\end{array}$ & Positif (Positive) & Ringan (Light) \\
\hline \multirow{3}{*}{$\begin{array}{l}\mathrm{E} 3=\text { Formalin } 300 \mathrm{mg} / \mathrm{L} \\
\mathrm{E} 3=\text { Formaldehyd } 300 \\
\mathrm{mg} / \mathrm{L}\end{array}$} & $\begin{array}{l}1 \text { jam perendaman } \\
1 \text { hour bathing }\end{array}$ & Positif (Positive) & Ringan (Light) \\
\hline & $\begin{array}{l}3 \text { jam perendaman } \\
3 \text { hours bathing }\end{array}$ & Positif (Positive) & Ringan (Light) \\
\hline & $\begin{array}{l}5 \text { jam perendaman } \\
5 \text { hours bathing }\end{array}$ & Positif (Positive) & Ringan (Light) \\
\hline
\end{tabular}

ing berikutnya yang mampu menginduksi perkembangan WSSV pada benur udang windu adalah penurunan dan peningkatan suhu air. Pada metode ini, tingkat infeksi WSSV pada benur tercatat dari tingkat infeksi ringan sampai sedang. Metode stressing dengan $\mathrm{pH}$ dan formalin relatif sama, dengan infeksi WSSV dari tingkat infeksi ringan sampai sedang. Stressing dengan peningkatan dan penurunan salinitas dalam penelitian ini masih kurang efektif untuk menginduksi perkembangan WSSV pada benur. Hal ini diduga disebabkan udang windu memiliki sifat toleransi terhadap salinitas yang cukup lebar sehingga penurunan dan peningkatan salinitas tidak menyebabkan udang windu stres. Namun demikian, perlu dilakukan kajian lebih lanjut efek salinitas secara bersama-sama dengan faktor lingkungan lainnya seperti oksigen, $\mathrm{pH}$, dan suhu.
Hasil penelitian ini menunjukkan bahwa terdapat indikasi bahwa semakin lama waktu perendaman, maka semakin tinggi tingkat infeksi WSSV pada benur. Hal ini menunjukkan bahwa replikasi WSSV pada benur meningkat sejalan dengan lamanya waktu perendaman. Du et al. (2008) melaporkan bahwa jumlah copi DNA WSSV pada cryfish meningkat dari $10^{6}$ virion/mg jaringan insang setelah 24 jam menjadi $10^{10}$ virion/mg jaringan insang setelah 48 jam uji tantang.

\section{KESIMPULAN DAN SARAN}

- Metode stressing yang terbaik dalam menginduksi perkembangan WSSV pada benur adalah berturut-turut oksigen (1 $\mathrm{mg} / \mathrm{L}, 3 \mathrm{mg} / \mathrm{L}$, dan $5 \mathrm{mg} / \mathrm{L}$ ), disusul dengan suhu (suhu $10^{\circ} \mathrm{C}$ dan $40^{\circ} \mathrm{C}$ ), $\mathrm{pH} 5$, dan penggunaan formalin. 


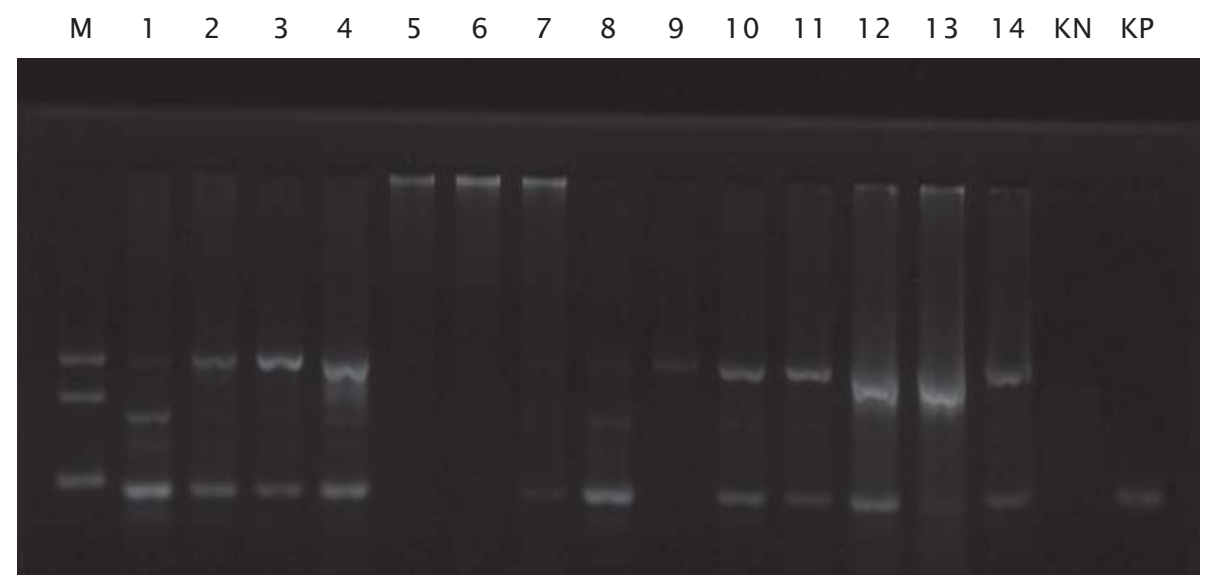

Keterangan (Note):

$\mathrm{M}=$ Marker (100 bp), $\mathrm{KP}=$ Kontrol positif (Positive control), $\mathrm{KN}=$ Kontrol negatif (Negative control), line 1-4 = Stressing oksigen (Stressing with oxygen), line 5-6 = Stressing dengan salinitas (Stressing with salinity), line 7 = Sebelum stressing (Before stressing), line 8-9= Stressing dengan $\mathrm{pH}$ (Stressing with $\mathrm{pH}$ ), line 10-11 = Stressing dengan formalin (Stressing with formaldehyde), line 12-14 = Stressing dengan suhu (Stressing with temperature)

Gambar 1. Visualisasi gel elektroforesis yang menampilkan hasil deteksi WSSV pada benur sebelum dan setelah uji stressing menggunakan suhu, salinitas, $\mathrm{pH}$, oksigen, dan formalin.

Figure 1. Gel electrophoresis visualization of WSSV detection in tiger shrimp post larvae before and after stressing with temperature, salinity, $\mathrm{pH}$, oxygen, and formaldehide

- Pada penelitian ini penggunaan salinitas sebagai stressor kurang efektif untuk menginduksi perkembangan WSSV pada benur.

- Ada kecenderungan semakin lama waktu perendaman, maka semakin memicu perkembangan WSSV pada benur udang windu.

\section{SARAN}

- Perlu dilakukan penelitian lebih lanjut tentang waktu perendaman lebih efektif untuk menginduksi perkembangan WSSV pada benur

- Perlu dilakukan kajian lebih lanjut efek salinitas secara bersama-sama dengan faktor lingkungan lainnya seperti oksigen, $\mathrm{pH}$, dan suhu dalam menginduksi perkembangan WSSV pada benur

\section{UCAPAN TERIMA KASIH}

Kepada rekan-rekan peneliti dan teknisi yang penuh dedikasi dan tanggung jawab membantu terlaksananya penelitian ini. Penelitian ini dibiayai oleh APBN T.A. 2011.

\section{DAFTAR ACUAN}

Anonymous. 2002. Instruction Manual. Detection and Prevention System for White Spot Syndrom Virus (WSSV). Taiwan, $18 \mathrm{pp}$.

Balasubramanian, G., Sudhakaran, R., Musthaq, S.S., Sarathi, M., \& Hameed, A.S.S. 2006. Studies on the inactivation of white spot syndrome virus of shrimp by physical and chemical treatments, and seaweed extracts tested in marine freshwater animal models. Journal of Fish Diseases, 29: 569572.

Cordova-Murueta, J.H., Garc1 'a-Carren, F.L., \& Navarrete-del-Toro, M.A. 2004. Effect of stressors on shrimp digestive enzymes from assays of feces: an alternate method of evaluation. Aquaculture, 233: 439-449.

Corsin, F., Turnbull, J.F., Mohan, C.V., Hao, N.V., \& Morgan, K.L. 2005. Use of epidemiological methods to limit the impact of white spot disease in Penaeus monodon farms of Vietnam and India. Aquaculture, 2: 21-30.

de la-Vega, E., Hall, M.R., Wilson, K.J., Reverter, A., Wood, R.G., \& Degnan, B.M. 2007. Stress- 
induced gene expression profiling in the black tiger shrimp Penaeus monodon. Physiol Genomics, 31: 126-138.

Du, H., Dai, W., Han, X., Li, W., Xu, Y., \& Xu, Z. 2008. Effect of temperature on viral replication of white spot syndrome virus in Procambarus clarkii. Aquaculture, 277: 149151.

Ivan, D.S. 2005. Biosekuriti budidaya Litopenaeus vannamei dan informasi beberapa penyakit. CP Prima, Surabaya, $26 \mathrm{hlm}$.

Lemonniera, H., Bernardb, E., Boglioa, E., Goaranta, C., \& Cochardb, J. C. 2004. Influence of sediment characteristics on shrimp physiology: $\mathrm{pH}$ as principal effect. Aquaculture, 240: 297-312.

Lu-Qing, P., Fang bo, Ling-Xu, J., \& Jing, L. 2007. The effect of temperature on selected immune parameters of white shrimp, Litopenaeus vannamei. Journal of the World Aquaculture Society, 38(2): 326-332.

Muliani, Parenrengi, A., Sulaeman, \& Atmomarsono, M. 2004. Prevalensi, intesitas, dan transmisi white Spot Syndrome Virus (WSSV) pada budidaya udang windu Penaeus monodon. J. Pen. Perik. Indonesia, 10: 103-110.

Muliani, Nurhidayah, \& Madeali, M.I. 2005. Deteksi White Spot Syndrome Virus (WSSV) pada induk udang windu Penaeus monodon dengan teknik polymerase chain reaction (PCR). Dalam Subagja, J., Samiarti, E., Kasiamdari, R.S., Pratiwi, R., Nuringtyas, T. R. (Eds.). Prosiding Seminar Nasional dan Kongres Biologi XIII dalam rangka Luxtrum $X$, Fakultas Biologi, Universitas Gajah Mada. Yogyakarta, hlm. 151-157.

Muliani, Tampangallo, B.R., \& Atmomarsono, M. 2011 . Penggunaan beberapa metode stressing pada skrining benur udang windu dengan teknik polymerase chain reaction (PCR). Dalam Taufiqurrahman, M., Winarno, A., Hardianto, D. (Eds.). Prosiding Seminar Nasional Kelautan VII. Universitas Hang Tua. Surabaya, hlm. B2-63-B274.

Murdjani, Arifin, Z., Adiwidjaya, D., Komaruddin, U., Nur, A., Susanto, A., Taslihan, A., Ariawan, K., Mardjono, M., Sutikno, E., Supito, Latief, M. S., Cokarkin, C., \& Proyoutomo, T.P. 2007. Penerapan best management practices (BMP) pada budidaya udang windu (Penaeus monodon Fabricus) intensif. Departemen Kelautan dan Perikanan, Direktorat Jenderal Perikanan BudidayA, Balai Besar Pengembangan Budidaya Air Payau, Jepara, $67 \mathrm{hlm}$.
Natividad, K.D.T., Migo, M.V.P., Albaladejo, J.D., Magbanua, J P.V., Nomura, N., \& Matsumura, M. 2006. Stimultaneous PCR detection of two shrimp viruses (WSSV and MBV) in post larvae of Penaeus monodon in the Philippines. Aquaculture, 257: 142-149.

Peng, S.E., Lo, C.F., Lin, S.C., Chen, L.L., Chang, Y.S., Liu, K.F., Su, M.S., \& Kou, G.H. 2001. Performance of WSSV-infected and WSSVnegative Penaeus monodon post larvae in culture ponds. Dis. Aquat. Org., 46: 165172.

Sanchez-Martinez, J.G., Aguirre-Guzman, G., \& Mejia-Ruiz, H. 2007. White Spot Syndrome Virus in cultured shrimp: A review. Aquaculture, 38: 1,339-1,354.

Sritunyalucksana, K., Srisala, J., McColl, Nielsen, L., \& Flegel, T. W. 2006. Comparison of PCR testing methods for White Spot Syndrome Virus (WSSV) infection in penaeid shrimp. Aquaculture, 255: 95-104.

Sulandari, S. \& Zein, M.S. 2003. Panduan praktis Laboratorium DNA. Bidang Zoologi. Pusat Penelitian Biologi. Lembaga Ilmu Pengetahuan Indonesia, $125 \mathrm{hlm}$.

Supriyadi, H., Taukhid, Sunarto, A., \& Koesharyani, I. 2005. Prevalensi infeksi White Spot Syndrome Virus (WSSV) pada induk udang windu (Penaeus monodon) hasil tangkapan dari alam. J. Pen. Perik. Indonesia, 11: 69-73.

Suwanto, A., Yogiara, Suryanto, D., Tan, I., \& Puspitasari, E. 2000. Selected protocols. Training Course on Advances in Molecular Biology Techniques to Assess Microbial Diversity. Bogor, $28 \mathrm{pp}$.

Tendencia, E.A., Bosma, R.H., \& Verreth, J.A.J. 2010. WSSV risk factor related to water physico-chemical properties and microflora in semi-intensive Penaeus monodon culture ponds in the Philippines. Aquaculture, 302: 164-168.

Vidal, O.M., Granja, C.B., Aranguren, F., Brock, J.A., \& Salazar, M. 2001. A profound effect of hypothermania on survival of Litopenaeus vannamei juveniles infected with White Spot Syndrome Virus. J. World. Aqua. Soc., 32: 364-372.

You, X.X., Su, Y.Q., Mao, Y., Liu, M., Wang, J., Zhang, M., \& Wu, C. 2010. Effect of high water temperature on mortality, immun response and viral replication of WSSVinfected Marsupenaeus japonicus juveniles and adults. Aquaculture, 305: 133-137. 